\title{
Amelioration of endothelial dysfunction by sodium glucose co-transporter 2 inhibitors: pieces of the puzzle explaining their cardiovascular protection
}

Xiaoling $\mathrm{Li}^{1}$, Benedikt Preckel ${ }^{1}$, Jeroen Hermanides ${ }^{1}$, Markus Hollmann ${ }^{1}$, Coert Zuurbier ${ }^{1}$, and Nina Weber ${ }^{1}$

${ }^{1}$ Amsterdam UMC Location AMC

January 19, 2022

\begin{abstract}
Sodium glucose co-transporter 2 inhibitors (SGLT-2i's) significantly improve cardiovascular outcome in both diabetic and nondiabetic patients. Preclinical studies suggest that SGLT-2i's directly affect endothelial function in a glucose-independent manner. The effects of SGLT-2i's include reduction of oxidative stress and inflammatory reaction in endothelial cells. Furthermore, SGLT2i's have been shown to restore endothelial-related vasodilation and to regulate angiogenesis. The favorable cardiovascular effects of SGLT-2i's might be mediated via multiple pathways: 1) by inhibition of the overactive sodium-hydrogen exchanger; 2) by reduction of nicotinamide adenine dinucleotide phosphate oxidases expression; 3) by alleviation of mitochondrial injury; 4) by the suppression of inflammatory-related signaling pathways (e.g. by affecting nuclear factor kappa beta); 5) by modulation of glycolysis, as well as 6) by restoring impaired nitric oxide bioavailability. This review focuses on the most recent progress and existing gaps in preclinical investigations concerning the direct effects of SGLT-2i's on endothelial dysfunction and their underlying mechanisms.
\end{abstract}

Amelioration of endothelial dysfunction by sodium glucose co-transporter 2 inhibitors: pieces of the puzzle explaining their cardiovascular protection

Xiaoling Li ${ }^{1}$, Benedikt Preckel ${ }^{1}$, Jeroen Hermanides ${ }^{1}$, Markus W. Hollmann ${ }^{1}$,

Coert J. Zuurbier ${ }^{1}$, Nina C. Weber ${ }^{1}$

${ }^{1}$ Amsterdam, University Medical Centers, location AMC, Department of Anesthesiology - Laboratory of Experimental Intensive Care and Anesthesiology (L.E.I.C.A.), Cardiovascular Science, Meibergdreef 11, 1105 AZ Amsterdam, The Netherlands

\section{Corresponding author:}

Dr. Nina C. Weber, PhD

Amsterdam, University Medical Centers, location AMC, Department of Anesthesiology - Laboratory of Experimental Intensive Care and Anesthesiology (L.E.I.C.A.), Cardiovascular Science, Meibergdreef 11, 1105 AZ Amsterdam, The Netherlands

N.C.Hauck@amsterdamumc.nl

Word Count : 5738 words.

Acknowledgements: XL is supported by Chinese Scholarship Council (CSC NO. 2019XXXX0054).

Conflict of interest statement: No conflict of interest to be disclosed. 


\section{Abstract (150 words)}

Sodium glucose co-transporter 2 inhibitors (SGLT-2i's) significantly improve cardiovascular outcome in both diabetic and non-diabetic patients. Preclinical studies suggest that SGLT-2i's directly affect endothelial function in a glucose-independent manner. The effects of SGLT-2i's include reduction of oxidative stress and inflammatory reaction in endothelial cells. Furthermore, SGLT2i's have been shown to restore endothelialrelated vasodilation and to regulate angiogenesis. The favorable cardiovascular effects of SGLT-2i's might be mediated via multiple pathways: 1) by inhibition of the overactive sodium-hydrogen exchanger; 2) by reduction of nicotinamide adenine dinucleotide phosphate oxidases expression; 3 ) by alleviation of mitochondrial injury; 4) by the suppression of inflammatory-related signaling pathways (e.g. by affecting nuclear factor kappa beta); 5) by modulation of glycolysis, as well as 6) by restoring impaired nitric oxide bioavailability. This review focuses on the most recent progress and existing gaps in preclinical investigations concerning the direct effects of SGLT-2i's on endothelial dysfunction and their underlying mechanisms.

Key words: sodium glucose co-transporter 2 inhibitors (SGLT-2i's); endothelial cell (EC) dysfunction; sodium-hydrogen exchanger (NHE); reactive oxygen species (ROS), inflammation

\section{Abbreviations}

\begin{tabular}{ll}
\hline Abbreviations & Terms \\
\hline AGEs & Advanced glycation end products \\
Akt & Protein kinase B \\
AMPK & Adenosine monophosphate-activated protein kinase \\
Ang II & Angiotensin II \\
Ca & Calcium \\
CANA & Canagliflozin \\
CM & Cardiomyocyte \\
CMEC & Cardiac microvascular endothelial cell \\
DAPA & Dapagliflozin \\
DM & Diabetes mellitus \\
EC & Endothelial cell \\
EMPA & Empagliflozin \\
eNOS & Endothelial nitric oxide synthase \\
ERK & Extracellular signal regulated kinase \\
GADPH & Glyceraldehydes-3-phosphate dehydrogenase \\
GCX & Glycocalyx \\
HAEC & Human aortic endothelial cell \\
HCAEC & Human coronary artery endothelial cell \\
HF & Heart failure \\
HFpEF & Heart failure with preserved ejection fraction \\
HIF-1 $\alpha$ & Hypoxia-induced factor-1 $\alpha$ \\
HKII & Hexokinase II \\
HUVEC & Human umbilical vein endothelial cell \\
ICAM-1 & Intracellular adhesion molecule 1 \\
IL & Interleukin \\
JNK & c-Jun N terminal kinase \\
MAPK & Mitogen-activated protein kinase \\
mtROS & Mitochondrial reactive oxidative species \\
NF- $x$ B & Nuclear factor kappa B \\
NHE & Sodium-hydrogen exchanger \\
NLRP3 & NOD-like receptor pyrin domain containing 3 \\
NO & Nitric oxide \\
NOX & Nicotinamide adenine dinucleotide phosphate oxidase \\
&
\end{tabular}




\begin{tabular}{ll}
\hline Abbreviations & Terms \\
\hline PI3k & Phosphatidylinositol 3 kinase \\
PKC & Protein kinase C \\
PON & Ponatinib \\
RAGE & Receptor for advanced glycation end products \\
ROS & Reactive oxidative species \\
SFK & Src Family kinase \\
SGLT-1/2 & Sodium glucose co-transporter $1 / 2$ \\
SGLT-2i's & Sodium glucose co-transporter 2 inhibitors \\
SMC & Smooth muscle cell \\
TNF- $\alpha$ & Tumor necrosis factor- $\alpha$ \\
VCAM-1 & Vascular cell adhesion molecule 1 \\
VE-cadherin & Vascular endothelial cadherin \\
VEGF & Vascular endothelial growth factor \\
\hline
\end{tabular}

\section{Introduction}

Patients with diabetes mellitus (DM) more frequently suffer from heart failure (HF), in particular heart failure with preserved ejection fraction (HFpEF), than individuals without DM (Seferovic et al. , 2018). Sodium glucose co-transporter 2 inhibitors (SGLT-2i's), a novel class of glucose-lowering drugs, significantly reduce the risk of cardiovascular death and hospitalisation in patients with existing HF, regardless of the presence of DM (Zinman et al. , 2015; Nealet al. , 2017; Wiviott et al. , 2019; Packer et al. , 2020). Treatment with empagliflozin (EMPA) also reduces the combined outcome of worsening HF, rehospitalization of HF and death for HF in patients with acute HF (Damman et al. , 2020). Recently, the EMPEROR-Preserved phase III trial has established EMPA as the first potential therapy capable to improve cardiovascular outcome in patients suffering from HFpEF (Anker et al. , 2021). Until today, the exact mechanisms underlying these "off-target" effects of SGLT-2i's remain largely unknown. Previous studies have highlighted the direct cardiac effects of SGLT-2i's (Packer, 2020; Kleinbongard et al. , 2020), which are mediated by alleviation of oxidative stress, inflammation, apoptosis, and calcium $\left(\mathrm{Ca}^{2+}\right)$ overload of cardiomyocytes $(\mathrm{CMs})$ (Uthman et al. , 2018; Trum et al. , 2021).

The PROMIS-HFpEF trial has prospectively demonstrated a high prevalence of coronary microvascular disorder and systemic endothelial dysfunction in patients with HF (Shah et al. , 2018). Endothelial cells (ECs) form a monolayer over the inner surface of vessels (Kruger-Gengeet al. , 2019). In the adult human heart, ECs account for $12.2 \%$ of total cells within the arterial tissues and $7.8 \%$ within the ventricular regions (Litvinukova et al. , 2020). Physiologically, ECs serve to maintain cardiovascular function by ensuring the production of endothelium-derived vasoactive factors, preventing monocyte adhesion and platelet aggregation, regulating the proliferation of smooth muscle cells (SMCs) as well as the contraction and relaxation of CMs (Monteiroet al. , 2019). In patients with diabetes, hyperglycemia impairs endothelial function and ultimately causes the development of macro- and micro- vascular complications (Shi et al. , 2017). Thus, ECs might serve as a novel target to improve cardiac function of patients with HF.

Previous studies have shown that SGLT-2i's directly ameliorate endothelial dysfunction in both euglycaemic and hyperglycaemic conditions (Alshnbari et al. , 2020; Durante et al. , 2021; Salvatore et al. ,2021) and that EMPA mitigates endothelial and cardiac dysfunction in patients with HFpEF via reducing inflammatoryoxidative pathways (Kolijn et al. , 2020). Our current manuscript focuses on the potential role of improved endothelial function as an indispensable contributor to the enhanced cardiac function in patients receiving SGLT-2i's. We will review the current data and most recent progress in preclinical investigations concerning the direct effects of SGLT-2i's on endothelial dysfunction, with the aim to improve the understanding of their compelling cardiovascular effect on patients with HF.

\section{SGLT-2i's inhibit reactive oxygen species (ROS) production in ECs}




\subsection{Mechanisms behind increased ROS production in ECs}

At moderate concentrations, ROS play an important role in maintaining the proliferation and survival of ECs, but excessive ROS have detrimental effects on the vascular system (Forstermann et al. , 2017). In patients with DM, hyperglycaemia accelerates protein glycation and forms advanced glycation end products (AGEs) (Kay et al. , 2016). These AGEs bind with cell surface receptors for AGEs (RAGE) to activate downstream signaling pathways, such as extracellular signal-regulated kinase (ERK), and subsequently increase ROS production (Yuan et al. , 2019). Excessive ROS also trigger nuclear poly ADP-ribose polymerase, which inhibits activity of glyceraldehydes-3-phosphate dehydrogenase (GADPH) and activates the polyol pathway of glucose (Giri et al. , 2018). Activated polyol pathway produces ROS via depleting nicotinamide adenine dinucleotide phosphate and glutathione, as well increasing the oxidation of nicotinamide adenine dinucleotide hydrogen during the conversion of sorbitol to fructose. Inhibition of GADPH also accelerates the generation of diacylglycerol, subsequently activating protein kinase $\mathrm{C}$ (PKC) and stimulating nicotinamide adenine dinucleotide phosphate oxidases (NOXs) to generate additional ROS (Yuan et al. , 2019). Mitochondria are the central regulators for aerobic energy generation, and ROS are the essential by-product during this process. Diabetes and hyperglycemia disrupt the mitochondrial respiratory chain and alter mitochondrial ultrastructure (e.g. mitochondrial fission and fusion), thereby increasing the ROS production within mitochondria (Forresteret al. , 2018; Brownlee, 2001). Hyperglycemia upregulates both abundance and activity of the sodium-hydrogen exchanger (NHE) within ECs (Klug et al. , 2021). Activated NHE promotes the influx of sodium influx and enhances intracellular calcium $\left(\mathrm{Ca}^{2+}\right)$ via triggering sodium-calcium exchanger (Baartscheer et al. , 2017). Increased intracellular sodium $\left(\mathrm{Na}^{+}\right)$triggers the sodium-calcium exchanger (NCX) and enhances calcium $\left(\mathrm{Ca}^{2+}\right)$ influx into the cytosol. The increased cytosolic $\mathrm{Ca}^{2+}$ then stimulates the PKC-NOXs pathway, which further increases ROS production (Rastogi et al. , 2016). Recently, Uthman et al have directly proven the causal link between NHE activity and oxidative stress in ECs: tumor necrosis factor- $\alpha$ (TNF- $\alpha$ ) enhanced NHE activity and intracellular sodium $\left(\mathrm{Na}^{+}\right)$, as well ROS production, and the increased ROS generation was mitigated by cariporide, a potent inhibitor for NHE. The crucial role of NHE/ $\mathrm{Na}^{+}$-axis in inflammatory related oxidative stress was further supported by the fact that sodium pump inhibitor ouabain increased intracellular $\mathrm{Na}^{+}$and ROS production in human ECs (Uthman et al. , 2022).

Excessive ROS increase vascular tone and undermine cardiac inotropic function, contributing to cardiomyopathy (Ritchie et al. , 2020). Oxidative stress causes endothelial nitric oxide synthase (eNOS) uncoupling and impairs NO production, the key vasodilator. ROS produced by NOXs also oxidize the sarcoendoplasmic reticulum calcium transport ATPase and limit the sensitivity of SMC to NO (Griendling et al. , 2021). Besides, ROS induce vascular stiffness via upregulating the expression of vasoactive factors like vascular endothelial growth factor (VEGF) and extracellular proteins like matrix metalloproteinases (Griendling et al. , 2021). Vascular remodeling elevates blood pressure and increases the intensity of cyclic stretch caused by vasoconstriction-dilation circles (Ohishi, 2018). Enhanced stretch might exacerbate oxidative stress via upregulating expression of NOXs in ECs, further increasing ROS production within in ECs (Li et al. , 2021). Besides, oscillatory shear stress created by disturbed blood flow also induces oxidative stress in ECs via activating NOXs (Siu et al. , 2016).

Depletion of nitric oxide (NO) is a crucial mediator for ROS related cardiac dysfunction (Shah et al. , 2021). EC-derived NO triggers soluble guanylate cyclase (cGMP) and protein kinase G (PKG) of adjacent CMs and leads to the phosphorylation of troponin I and reduction of myofilament $\mathrm{Ca}^{2+}$ sensitivity, thus enhancing myocardial relaxation in both isolated CMs and whole hearts (Królet al. , 2021; Feil et al. ). Activation of the NO/cGMP/PKG signaling pathway also maintains phosphorylation of titin within CMs and prevents the development of cardiac hypertrophy (Shah et al. , 2021). Moreover, oxidative stress leads to increased secretion of pro-inflammatory cytokines and chemokines from ECs, as well as upregulated expression of adhesion molecules and enhanced monocyte-endothelial attachment (Yuan et al. , 2019). Intensified ROS production activates src family kinase (SFK) to phosphorylate vascular endothelial-cadherin (VE-cadherin), leading to VE-cadherin internalisation and adherens junction disruption. Activated SFK also promotes the transformation from $\mathrm{G}$ actin to $\mathrm{F}$ actin to generate stress fibres under the cellular membrane, increasing the 
intracellular tension (Zhang et al. , 2017). ROS are also involved in the endothelial dysfunction induced by stretch and oscillatory shear stress through intracellular cascades, such as mitogen-activated protein kinase p38 (p38 MAPK), ERK, c-Jun N-terminal kinase (JNK) and nuclear factor kappa B (NF- xB) (Lehoux, 2006). The pivotal role of EC-derived ROS in development of cardiovascular disease is summarised in Figure 1.

\subsection{Anti-oxidative effect of SGLT-2i's}

Mounting evidence reveals a class effect of ROS inhibition for SGLT-2i's. In vivo studies showed that ipragliflozin decreased urinary 8-hydroxy-2'-deoxyguanosine (a marker for DNA oxidative injury) in hyperglycaemic mice (Salim et al. , 2016), and dapagliflozin (DAPA) attenuated elevated vascular ROS generation in aortic atherosclerotic tissues of diabetic mice (Leng et al. , 2016). However, it might be considered that these observed ROS inhibitory effects of SGLT-2i's were mediated by the decreased blood glucose in mice with diabetes.

Live cell imaging suggested that SGLT-2i's directly inhibited inflammation-stimulated ROS production within human ECs from both venous and arterial vessels (Uthman et al. , 2019). Two other studies showed that EMPA reduced ROS production within cardiac microvascular endothelial cells (CMECs) exposed to pro-inflammatory cytokines and uremic acid (Juni et al. , 2019; Juni et al. , 2021). By preventing ROS accumulation within ECs, EMPA restored NO bioavailability in co-cultured CMs, indicating that the ROS inhibitory capacity of SGLT-2i's contributes to the improvement of contraction and relaxation of adjacent CMs through an endothelial-NO pathway (Juni et al. , 2019; Juni et al. , 2021). A more recent study reported a novel ROS inhibitory effect of SGLT-2i's in human coronary artery endothelial cells (HCAECs) undergoing enhanced cyclic stretch, suggesting that SGLT-2i's might also alleviate oxidative stress caused by mechanical forces (Li et al. , 2021). This study firstly showed that SGLT-2i's prevented the loss of VEcadherin and alleviated barrier dysfunction in HCAECs undergoing enhanced stretch, which was mediated by their ROS inhibitory effect (Li et al. , 2021).

\subsection{Potential mechanisms underlying ROS inhibition by SGLT-2i's}

Several factors contribute to the anti-oxidative effect of SGLT-2i's. SGLT-2i's revert upregulation of NOXs and inhibit oxidative stress in the macro- and micro- vascular system (Ganbaatar et al. , 2020; Kuno et al. , 2020). In diabetic mice, EMPA reduced NOX2 expression at messenger RNA (mRNA) levels in aortic endothelium (Ganbaatar et al. , 2020). Correspondingly, EMPA also suppressed the increase of NOX2 and NOX4 in renal tissue of rats with acute kidney injury (Kuno et al. , 2020). An in vitro study showed that EMPA exerted a similar inhibitory capacity like GKT136901, a specific inhibitor for NOX1 and NOX4, on ROS generation in HCAECs undergoing enhanced stretch. Combination of EMPA and GKT136901 did not further reduce the stretch-induced ROS production, suggesting that the anti-oxidative effect of EMPA is mediated via NOXs (Li et al. , 2021). Furthermore, EMPA prevented hyperglycaemia-induced mitochondrial disruption, thereby attenuating the overproduction of cytosolic ROS and mitochondrial ROS (mtROS) in ECs isolated from mice and humans (Juniet al. , 2021; Zhou et al. , 2018). This mechanism is further supported by the fact that induction of mitochondrial fission abrogated the inhibitory effects of EMPA on mtROS in mice CMECs (Zhouet al. , 2018).

Another potential mechanism that might explain the antioxidant effects of SGLT2i's is the direct inhibition of the sodium-hydrogen exchanger (NHE) by SGLT2i's, firstly discovered in CMs (Baartscheer et al. , 2017; Uthman et al. , 2018). A recent study from our laboratory showed that $10 \mu \mathrm{M}$ cariporide blocked the increase of oxidative stress in HCAECs undergoing enhanced cyclic stretch, and this effect of cariporide on ROS production was not further enhanced when combined with EMPA. These data indirectly suggest the involvement of NHE in the anti-oxidative capacity of EMPA in ECs (Li et al. , 2021). For the first time, Uthman et al directly proved that EMPA inhibited ROS production in ECs via NHE inhibition: EMPA treatment lowered the NHE activity and $\mathrm{Na}^{+}$concentration in human ECs triggered by TNF- $\alpha$ (measured with SNARF-AM and SBFI-AM fluorescence probes respectively), and also mitigated the increased ROS production. The combination of EMPA and cariporide did not demonstrate additional ROS reduction in 
cells, showing that EMPA reduced TNF- $\alpha$ induced ROS production via NHE inhibition (Uthman et al. , 2022).

Yet, there is still an ongoing discussion regarding the role of NHE in the inhibitory effect on ROS of SGLT2i's. In support of our finding, Cappetta et al. previously reported NHE inhibition by DAPA in "nonstimulated" human umbilical vein endothelial cells (HUVECs) (Cappetta et al. , 2020). In contrast, using cardiac microvascular ECs exposed to uremic serum, Juni et al. recently observed a stronger ROS inhibitory capacity of $1 \mu \mathrm{M}$ EMPA when compared to $10 \mu \mathrm{M}$ cariporide (63\% vs $38 \%$ ), indicating that part of the anti-oxidative effect of EMPA might be unrelated to NHE inhibition (Juni et al. , 2021). Chung et al. reported a neutral effect of EMPA (1-30 $\mu \mathrm{M})$ on NHE activity within isolated rat CMs (Chung et al. , 2020), which is in contrast to the studies of Baartscheer et al., Uthman et al. and Zuurbier et al. showing that $1 \mu \mathrm{M}$ EMPA inhibited the NHE activity in both isolated cardiac myocytes and isolated intact hearts of different rodents (mice and rabbits) (Baartscheer et al. , 2017; Uthmanet al. , 2018; Zuurbier et al. , 2021). Diversities in the employed methodology might explain the differences between these studies.

The involvement of sodium glucose co-transporter $1 / 2$ (SGLT-1/2) in the anti-oxidative effect of SGLT-2i's has been recently investigated. Recent studies showed that high glucose and angiotensin II (Ang II) increased the expression of SGLT-1 and -2 in porcine ECs, and that EMPA showed an inhibitory effect on the induced SGLT-1/2 expression (Khemais-Benkhiat et al. , 2020; Park et al. , 2021). At 24 h, sotagliflozin (a dual inhibitor for SGLT-1 and -2) and empagliflozin abolished the Ang II-induced ROS production. Reduction of extracellular glucose and $\mathrm{Na}^{+}$concentrations significantly inhibited the pro-oxidant reaction to Ang II, indicating the crucial role of SGLT-1 and -2 in a glucose and sodium dependent ROS production (Parket al. , 2021). Intriguingly, the sustained oxidative stress triggered by Ang II could also be alleviated by inhibition of NHE, NCX and NOXs, further supporting the functional link between NHE/ $\mathrm{Na}^{+} / \mathrm{Ca}^{2+}$ pathway and ROS production by NOXs within ECs (Park et al. , 2021). However, expression of SGLT-2 in ECs is still a matter of debate, especially in the case of human cells. Mancini et al. showed the absence of SGLT-2 at mRNA level in HUVECs (Mancini et al. , 2018), corresponding with the most recent study of Juni et al. using human CMECs (Juni et al. , 2021). In contrast, using Western blot, Behnammanesh et al. detected the presence of SGLT-2 in human ECs (Behnammanesh et al. , 2019). Uthman et al. also reported a potential existence of SGLT-2 in human ECs at protein level with a commercially available antibody (Uthman et al. , 2019). But this signaling for SGLT-2 protein persisted after the target gene being silenced at mRNA level, and the qPCR revealed no existence of SGLT-2 (Uthman et al. , 2019).

\section{SGLT-2i's inhibit the inflammatory reaction of ECs upon different stimuli}

\subsection{Increased vascular inflammation in ECs}

During hyperglycaemia, binding of AGEs to RAGE elevates adhesion molecule expression, production of cytokines and growth factors via the activation of ERK, JNK, and phosphoinositol 3-kinase (PI3k) pathways. AGEs directly stimulate monocytes to produce inflammatory mediators like interleukins (ILs) and TNF- $\alpha$, and thereby further enhance local inflammation of the vascular wall (Jin et al. , 2018). Moreover, excessive production of ROS induces vascular inflammation in ECs via upregulating intercellular adhesion molecule 1 (ICAM-1) and vascular cell adhesion molecule 1 (VCAM-1) (Daiber et al. , 2020). The oxidative stress triggers cytokine secretion mainly in an "inflammasome-dependent" manner (Bai et al. , 2020). Briefly, ROS activate NF- $x \mathrm{~B}$ and upregulate the expression level of NOD-like receptor containing pyrin domain 3 (NLRP3) inflammasome as well as pro-IL-1 $\beta$. Then, NLRP3 inflammasome is activated through assembling of NLRP3, caspase-1 and apoptosis-associated speck-like protein containing a CARD (caspase activation and recruitment domain), forming a complex for the final production of active caspase-1, IL-1 $\beta$ and IL-18. This process is also accelerated by ROS (Ferrucci et al. , 2018; Toldoet al. , 2021). Intriguingly, pro-inflammatory mediators released during inflammation like TNF- $\alpha$ can induce ROS production, thus promoting the "vicious circle" of oxidative stress and inflammation (Yuanet al. , 2019).

\subsection{Anti-inflammatory capacity of SGLT-2i's}

A recent clinical trial revealed that 24-week treatment with EMPA significantly reduced serum ICAM-1 level 
and prevented leukocyte-endothelium interactions in patients with DM (Canet et al. , 2021). EMPA inhibited macrophage accumulation, as well the expression of monocyte chemoattractant protein- 1 and ICAM- 1 in the aortic arch of diabetic mice (Ganbaatar et al. , 2020) and DAPA attenuated the high-salt diet-induced upregulation of VCAM-1 in euglycaemic rats and lowered NF- $x$ B expression within rat ECs (Cappettaet al. , 2020). Another study showed that EMPA limited Ang II-induced abdominal aortic aneurysm in ApoE knockout mice, partially through inhibiting activation of p38 MAPK and NF- $x$ B in aortas, as well reducing macrophage infiltration within lesions (Ortega et al. , 2019).

Consistently, in vitro studies revealed that DAPA attenuated the increased ICAM-1 and VCAM-1 secretion of HUVECs exposed to hyperglycaemia or TNF- $\alpha$ for $24 \mathrm{~h}$ (Gaspari et al. , 2018) and that EMPA inhibited the TNF- $\alpha$ triggered leukocyte adhesion towards human ECs cultured under flow (Cooper et al. , 2019). However, the anti-inflammatory effect in Cooper's study was achieved by very with high concentration of EMPA $(50 \mu \mathrm{M})($ Cooper et al. , 2019). Uthman et al. reported a neutral effect of EMPA $(1 \mu \mathrm{M})$ on TNF$\alpha$-induced adhesion molecules expression in static human ECs (Uthman et al. , 2019). In the latter study, ICAM- 1 and VCAM- 1 were measured $4 \mathrm{~h}$ after TNF- $\alpha$ stimulation with flow cytometry, instead of using the supernatant of cell culture as in the study of Gaspari et al. (Uthman et al. , 2019; Gaspari et al. , 2018). The dosage of SGLT-2i's also differed in these two study (1 $\mu \mathrm{M}$ vs. 1-5 nM, respectively). Yet, lower doses of DAPA (1 and $10 \mathrm{nM}$ ) did not inhibit expression of adhesion molecules either in the study of Uthman et al (Uthman et al. , 2019). Additionally, static cells are not directly comparable to cells cultured under

flow. Static cells develop a thinner glycocalyx (GCX) layer than dynamically activated ECs, and the latter model is considered more physiologically relevant because in situ endothelial cells are constantly exposed to mechanical forces generated by blood flow (Chistiakov et al. , 2017; Haymet et al. , 2021).

Uthman et al. recently reported a compound-specific effect of canagliflozin (CANA) in inhibiting IL-6 secretion by HCAECs exposed to lipopolysaccharide (Uthman et al. , 2020). In this study, only CANA activated adenosine monophosphate-activated protein kinase (AMPK), while EMPA or DAPA did not alter AMPK phosphorylation in HCAECs (Uthmanet al. , 2020). The different impact on AMPK might partially explain the diverse effects of the three SGLT-2i's on vascular inflammation. Moreover, CANA-induced IL-6 reduction was significantly diminished after glycolytic hexokinase II (HKII) knockdown, revealing a novel anti-inflammatory mechanism of CANA via inhibiting glycolysis (Uthman et al. , 2020).

\section{SGLT-2i's restore impaired NO bioavailability}

\subsection{Mechanisms of reduced NO bioavailability in ECs}

Patients with HF show an increased vascular tone in both macro- and micro- vessels, mainly because of blunted NO bioavailability (Forstermann et al. , 2017). Physiologically, NO production in ECs is initiated by phosphorylation of eNOS via the PI3K/protein kinase B (Akt) pathway. Hyperglycaemia compromises NO generation by inhibiting the expression of eNOS as well as suppressing the phosphorylation of the active site of eNOS (e.g. Ser1177) (Meza et al. , 2019; Forstermann et al. , 2017). In addition, excessive ROS in ECs consumes NO, which can be prevented by anti-oxidative agents (Mezaet al. , 2019). Next to the above mentioned mechanisms, mechanical forces play a crucial role in modulating NO production within ECs. When exposed to unidirectional high shear stress (12-15 dyne $\left./ \mathrm{cm}^{2}\right)$, the GCX transduces mechanical stimulation to intracellular compartments and triggers diverse downstream pathways like PI3K/Akt/eNOS, thus promoting the release of NO (Chistiakovet al. , 2017). Increased blood glucose levels degrade endothelial GCX of diabetic mice (Zuurbier et al. , 2005), suggesting a potential interaction between hyperglycaemia and GCX in eNOS-dependent NO production.

\subsection{Restoration of NO by SGLT-2i's}

In vivo studies showed that SGLT-2i's restored the endothelium-dependent vasodilation in both hyperglycaemic and euglycaemic animals (Salim et al. , 2016; Sayour et al. , 2019). Additionally, in vitro studies showed that EMPA and DAPA reverted the loss of NO in human ECs exposed to TNF- $\alpha$ (Uthman et al. , 2019; Juni et al. , 2021). However, phosphorylation of eNOS at Ser1177 in isolated ECs was not affected by EMPA, the rescued NO bioavailability in isolated human ECs was most likely mediated by the ROS 
inhibitory capacity of SGLT-2i's (Uthman et al. , 2019; Juniet al. , 2021). In contrast, EMPA promoted eNOS phosphorylation via activating AMPK in ECs isolated from mice (Zhou et al. , 2018), which could be partially explained by species difference. Moreover, the studies of Uthman and Juni were performed within static ECs (Uthman et al. , 2019; Juni et al. , 2021). A further improvement in cellular studies could be the incorporation of dynamically activated ECs.

\section{SGLT-2i's revert disturbed angiogenesis of ECs}

\subsection{Pathological modulation of angiogenesis}

Angiogenesis is defined as the formation of new capillaries from established vessels. Physiologically, this process is limited to the embryonic and postnatal stage and rarely found within healthy adults, apart from female reproductive organs (Eelen et al. , 2020). Pathological alterations in angiogenesis are highly diverse in different organs/tissues. For example, excessive angiogenesis occurs in diabetic retinopathy/nephropathy, while the angiogenetic capacity is significantly impaired in cardiac and cerebral tissue of patients with DM (Okonkwo et al. , 2017). Growth factors like VEGFs play a key role in promoting vascular growth and remodeling, and they can be dramatically upregulated by hyperglycaemia, ROS and pro-inflammatory mediators like TNF- $\alpha$, but mostly by the lack of oxygen in respective organs. Local hypoxic conditions activate hypoxia-induced factor (HIF)-1 $\alpha$ and increase the expression of VEGFs (Apte et al. , 2019). Conditional knockout of HIF-1 $\alpha$ attenuated VEGF overproduction and prevented the development of diabetic retinopathy within mice, suggesting a crucial role of the HIF-1 $\alpha$ /VEGFs pathway in pathological angiogenesis (Lin et al. , 2011). Vasodilators like NO are temporarily increased during pregnancy and may promote placental angiogenesis, but whether this effect persists in adult tissue is unclear (Umapathy et al. , 2020).

\subsection{The effect of SGLT-2i's on angiogenesis}

The effect of SGLT-2i's on angiogenesis is still controversial. Previously, Zhou et al. demonstrated that EMPA promoted angiogenesis of CMECs in diabetic mice, thus improving myocardial microcirculatory perfusion and cardiac function (Zhou et al. , 2018). This study showed that EMPA preserved angiogenetic capacity of isolated CMECs through stabilization of F-actin. The effect of EMPA was nearly abolished when EMPA was combined with FCCP, a mitochondrial fission activator to promote mtROS generation (Zhou et al. , 2018). Excessive ROS arrested the cell cycle transition from G0/G1 to S and interrupted CMECs proliferation, which was re-established by EMPA and mdivi1 (an inhibitor for mitochondrial fission) (Zhou et al. , 2018). Taken together, prevention of mitochondrial fission and subsequent oxidative stress by EMPA was involved in its pro-angiogenetic effects on CMECs. Correspondingly, a recent study from Nikolaou et al. showed that chronic administration (6 weeks) of EMPA reduced myocardial infarct size after ischemiareperfusion in non-diabetic mice, and this cardioprotective effect of EMPA could be partially explained by the improved CMECs survival (Nikolaou et al. , 2021). An in vitro study with human ECs exposed to hypoxia/reoxygenation stress also proved that EMPA increased cellular viability via activating signal transducer and activator of transcription 3 pathway (Nikolaou et al. , 2021). Using human aortic endothelial cells (HAECs), another study revealed that the autophagy is also involved in the pro-angiogenic effect of EMPA. The anti-leukemia agent ponatinib (PON) induces vasculotoxicity via mitochondrial damage, while the autophagy-mediated removal of injured mitochondria represents a cardiovascular protective mechanism against the toxic insult of PON. HAECs exposed to PON showed decreases in autophagy marker expression (LC3-I/II), tube formation as well cell viability, which were reverted by EMPA (Madonna et al. , 2021).

In contrast, Behnammanesh et al. reported a robust anti-proliferative and anti-migration effect of CANA in HUVECs and HAECs (Behnammaneshet al. , 2019). In clinically relevant dosages, CANA (5 $\mu \mathrm{M}$ and 10 $\mu \mathrm{M})$ inhibited the proliferation of HUVECs by reducing the expression of cyclin A, as well as by reducing phosphorylation of the retinoblastoma protein, while EMPA and DAPA barely influenced the proliferative capacity of ECs in their physiological dosage (1-2 $\mu \mathrm{M})$ (Behnammaneshet al. , 2019; Devineni et al. , 2016; Tomlinson et al. , 2017). The anti-proliferative effect of CANA could also be beneficial: CANA suppressed the increased proliferation and tubular formation of HUVECs during co-culture with Huh7 and HepG2 (hepatocyte-derived carcinoma cell lines), as well the enhanced production of angiogenic cytokines 
(e.g. IL-8), thus inhibiting the growth of liver cancer (Kaji et al. , 2018). More recently, another study showed that CANA had a dosage-dependent inhibitory effect on the VEGF-A expression and angiogenesis of HUVECs co-cultured with HepG2 cell line (Luo et al. , 2021).

Several factors might explain the observed opposite effects of CANA and EMPA on angiogenesis. Firstly, these studies were performed with ECs under different "stress" conditions. Cells in the EMPA studies were activated with pathological stimuli (diabetes, hypoxia/reoxygenation and PON) that impaired their cellular viability and angiogenesis capacity (Zhou et al. , 2018; Nikolaou et al. , 2021; Madonnaet al. , 2021), while the anti-angiogenic effect of CANA was reported in "non-stimulated" cells or ECs co-cultured with cancer cells (Behnammanesh et al. , 2019; Kaji et al. , 2018; Luoet al. , 2021). The potential involvement of SGLT-1 is also of importance, considering that anti-proliferating effect seems to be compound-specific for CANA (Behnammanesh et al. , 2019). Compared with EMPA and DAPA, CANA is relatively less selective for SGLT-2 over SGLT-1, and the latter is highly expressed in human ECs (Ohgaki et al. , 2016). However, in a HepG2 and ECs co-culture model, CANA reduced glucose uptake and growth of liver cancer cells via inhibiting SGLT-2 rather than SGLT-1 (Kaji et al. , 2018). Moreover, the effect of SGLT-2i's on ECs proliferation and migration might vary among different organs/tissues, and more research is required to explain these existing differences.

\section{Summary and Perspective}

In summary, SGLT-2i's demonstrate prominent cardiovascular protective effects in patients with existing HF, with and without diabetes (Ankeret al. , 2021; Packer et al. , 2020). Whereas earlier studies focused on the direct impact of SGLT-2i's on CMs, recent work has also emphasised ECs as a promising therapeutic target of SGLT-2i's (Durante et al. , 2021; Salvatore et al. , 2021). Preclinical studies show that SGLT-2i's exert favorable effects against endothelial dysfunction, including inhibiting oxidative stress and inflammatory reactions, restoring NO bioavailability, and modulating angiogenesis (The major findings of discussed literatures are listed in Table 1). This property might contribute to the cardiovascular benefits observed in patients receiving SGLT-2i's (Figure 2).

However, there are lots of controversies concerning the mechanisms underlying these observed endothelial effects. Species differences can only partly explain these discrepancies, and in vivo studies using rats and mice are vulnerable to the influence of the animals biokinetic parameters, making it difficult to extrapolate the results to humans (Saeidnia et al. , 2015). Moreover, the relatively limited studies in human ECs are of high diversity in origin (micro- or macro- circulation) and developmental stage (adult or postnatal) of the cells (Alshnbari et al. , 2020). Further studies with CMECs are required, considering the high prevalence and clinical relevance of coronary microvascular dysfunction in patients with HF (Shah et al. , 2018). Remarkably, most of these in vitro studies are performed in static cells.

Taken together, given that endothelial dysfunction is a crucial promoter for the development of heart failure and that SGLT-2i's exert promising protective effects on ECs, SGLT-2i's have a great potential in the treatment of cardiovascular disease. Investigations regarding the direct endothelial effect of SGLT-2i's are needed for a better understanding of the mechanisms underlying these cardiovascular effects.

\section{Nomenclature of Targets and Ligands}

Key protein targets and ligands in this article are hyperlinked to corresponding entries in the IUPHAR/BPS Guide to PHARMACOLOGY http://www.guidetopharmacology.org and are permanently archived in the Concise Guide to PHARMACOLOGY 2021/22 (Alexander et al. , 2021; Alexander et al. , 2021; Alexander et al. , 2021).

\section{Author Contributions}

Original draft preparation: XL, BP and NCW; revision and editing: NCW, BP, CJZ, MWH,JH and XL; conceptualization: NCW, BP, CJZ, MWH and JH; literature search and analysis: XL and NCW; figure/table preparation: XL. 
Table 1 Major findings of the direct endothelial effects of SGLT-2i's

\begin{tabular}{|c|c|c|c|c|}
\hline References & Cells/Tissues & Drug (Dosage) & $\begin{array}{l}\text { Stimulant } \\
\text { (Dosage) }\end{array}$ & Major findings \\
\hline $\begin{array}{l}\text { Behnammanesh et } \\
\text { al., } 2019\end{array}$ & $\begin{array}{l}\text { HUVECs HAECs } \\
\text { Mice aortic ECs }\end{array}$ & $\begin{array}{l}\text { CANA }(0-50 \mu \mathrm{M}) / \\
1-3 \mathrm{~d}\end{array}$ & $\cdots$ & $\begin{array}{l}\text { Angiogenesis - } \\
\text { Cell proliferation - } \\
\text { Cyclin A and } \\
\text { retinoblastoma } \\
\text { phosphorylation - }\end{array}$ \\
\hline \multirow{2}{*}{$\begin{array}{l}\text { Cappetta et al., } \\
2020\end{array}$} & HUVECs & DAPA $(1 \mu \mathrm{M})$ & $\cdots$ & NHE activity - \\
\hline & Rat vasculature & $\begin{array}{l}\text { DAPA }(0.1 \\
\mathrm{mg} / \mathrm{kg} / \mathrm{d}) / 6 \mathrm{w}\end{array}$ & $\begin{array}{l}\text { High-salt }(8 \% \\
\mathrm{NaCl}) / 11 \mathrm{w}\end{array}$ & VCAM-1 - NF- $x \mathrm{~B}$ \\
\hline Cooper et al., 2019 & HAECs & $\begin{array}{l}\mathrm{EMPA}(50 \mu \mathrm{M}) / 24 \\
\mathrm{~h}\end{array}$ & $\begin{array}{l}\text { TNF- } \alpha(10 \mu \mathrm{g} / \mathrm{ml}) / \\
24 \mathrm{~h} \text { Wall shear } \\
\text { stress }(10 \\
\text { dyne/cm } 2) / 24 \mathrm{~h}\end{array}$ & $\begin{array}{l}\text { Leukocyte- } \\
\text { endothelium } \\
\text { adhesion - } \\
\text { Glycocalyx integrity }\end{array}$ \\
\hline $\begin{array}{l}\text { Ganbaatar et al., } \\
2020\end{array}$ & $\begin{array}{l}\text { Abdominal aorta } \\
\text { of Apo } \mathrm{E}^{-/-} \text {mice }\end{array}$ & $\begin{array}{l}\operatorname{EMPA}(20 \\
\mathrm{mg} / \mathrm{kg} / \mathrm{d}) / 8-12 \mathrm{w}\end{array}$ & $\mathrm{STZ}$ (75 mg/kg) & $\begin{array}{l}\text { NOX } 2- \\
\text { Macrophage } \\
\text { accumulation - } \\
\text { Monocyte } \\
\text { chemoattractant } \\
\text { protein-1 - } \\
\text { ICAM-1- }\end{array}$ \\
\hline \multirow[t]{2}{*}{ Gaspari et al., 2018} & HUVECs & $\begin{array}{l}\text { DAPA (1 nM-1 } \\
\mathrm{mM}) / 24 \mathrm{~h}\end{array}$ & $\begin{array}{l}\text { TNF- } \alpha(10 \mathrm{ng} / \mathrm{ml}) / \\
24 \mathrm{~h} \\
\text { Hyperglycaemia } \\
(10-30 \mathrm{mM}) / 24 \mathrm{~h}\end{array}$ & $\begin{array}{l}\text { ICAM-1 - } \\
\text { VCAM-1 - NF- } x \text { B }\end{array}$ \\
\hline & $\begin{array}{l}\text { Aortic sections of } \\
\text { Apo } \mathrm{E}^{-/-} \text {mice }\end{array}$ & $\begin{array}{l}\text { DAPA }(1 \\
\mathrm{mg} / \mathrm{kg} / \mathrm{d}) / 4 \mathrm{w}\end{array}$ & $\begin{array}{l}\text { High-fat diet }(22 \% \\
\text { fat }+0.15 \% \\
\text { cholesterol }) / 20 \mathrm{w}\end{array}$ & ICAM-1 - \\
\hline Juni et al., 2019 & Human CMECs & $\begin{array}{l}\text { EMPA }(1 \mu \mathrm{M}) / 6 \\
\mathrm{~h}\end{array}$ & $\begin{array}{l}\mathrm{TNF}-\alpha(10 \\
\mathrm{ng} / \mathrm{ml}) / 6 \mathrm{~h}\end{array}$ & $\begin{array}{l}\text { Cytoplasmatic } \\
\text { ROS - } \\
\text { Mitochondrial } \\
\text { ROS — NO } \\
\text { bioavailability — }\end{array}$ \\
\hline Juni et al., 2021 & Human CMECs & EMPA $(1 \mu \mathrm{M}) / 6 \mathrm{~h}$ & $\begin{array}{l}\text { Uremic serum } \\
(15 \%) / 6 \mathrm{~h}\end{array}$ & $\begin{array}{l}\text { Cytoplasmatic ROS } \\
\text { - Mitochondrial } \\
\text { MOS - } \\
\text { Mitochondrial } \\
\text { fragmentation - } \\
\text { NO bioavailability } \\
\text { - }\end{array}$ \\
\hline
\end{tabular}




\begin{tabular}{|c|c|c|c|c|}
\hline References & Cells/Tissues & Drug (Dosage) & $\begin{array}{l}\text { Stimulant } \\
\text { (Dosage) }\end{array}$ & Major findings \\
\hline Kaji et al., 2018 & HUVECs & $\begin{array}{l}\text { CANA }(10 \\
\mu \mathrm{M}) / 12 \mathrm{~h}\end{array}$ & $\begin{array}{l}\text { Co-culture with } \\
\text { Huh7 and } \\
\text { HepG2/24 h }\end{array}$ & $\begin{array}{l}\text { HUVEC } \\
\text { proliferation - } \\
\text { Tubular } \\
\text { formation - IL-8 } \\
- \text { Angiogenin - } \\
\text { Metalloproteinase- } \\
1\end{array}$ \\
\hline \multirow[t]{2}{*}{$\begin{array}{l}\text { Khemais-Benkhiat } \\
\text { et al., } 2020\end{array}$} & $\begin{array}{l}\text { Porcine coronary } \\
\text { artery ECs }\end{array}$ & $\begin{array}{l}\text { EMPA }(0.1-100 \\
\mathrm{nM}) / 30 \mathrm{~min}-96 \mathrm{~h}\end{array}$ & $\begin{array}{l}\text { High glucose }(25 \\
\mathrm{mmol} / \mathrm{L}) / 48 \text { or } 96 \mathrm{~h}\end{array}$ & $\begin{array}{l}\text { Senescence } \\
\text { associated-beta- } \\
\text { galactosidase - } \\
\text { p-21 \& p-16 protein } \\
\text { - ROS - NOX - } \\
\text { eNOS \& NO- } \\
\text { Glucose uptake - } \\
\text { VCAM-1 - }\end{array}$ \\
\hline & $\begin{array}{l}\text { Porcine coronary } \\
\text { segment }\end{array}$ & $\begin{array}{l}\text { EMPA }(100 \mathrm{nM}) / \\
30 \mathrm{~min}\end{array}$ & $\begin{array}{l}\text { High glucose }(25 \\
\mathrm{mmol} / \mathrm{L}) / 24 \mathrm{~h}\end{array}$ & $\begin{array}{l}\text { SGLT-1 \& 2- } \\
\text { eNOS - VCAM-1 }\end{array}$ \\
\hline Leng et al., 2016 & $\begin{array}{l}\text { Aortic sections of } \\
\text { Apo } E^{-/-} \text {mice }\end{array}$ & $\begin{array}{l}\text { DAPA }(1.0 \\
\mathrm{mg} / \mathrm{kg} / \mathrm{d}) / 12 \mathrm{w}\end{array}$ & $\begin{array}{l}\text { STZ }(130 \mathrm{mg} / \mathrm{kg}) \\
\text { + high-fat diet }(15 \% \\
\text { fat+0.15\% } \\
\text { cholesterol }) / 4 \mathrm{w}\end{array}$ & $\begin{array}{l}\text { ROS - NLRP3 } \\
\text { inflammasome - }\end{array}$ \\
\hline Li et al., 2021 & HCAECs & $\begin{array}{l}\text { EMPA }(1 \mu \mathrm{M}) / 24 \\
\mathrm{~h} \text { DAPA }(1 \\
\mu \mathrm{M}) / 24 \mathrm{~h} \text { CANA } \\
(3 \mu \mathrm{M}) / 24 \mathrm{~h}\end{array}$ & $\begin{array}{l}\text { Cyclic stretch (1 } \\
\mathrm{Hz}, 10 \%) / 24 \mathrm{~h}\end{array}$ & $\begin{array}{l}\text { ROS - Cell } \\
\text { permeability - } \\
\text { VE-cadherin - }\end{array}$ \\
\hline Luo et al., 2021 & HUVECs & $\begin{array}{l}\text { CANA }(10 \& 20 \\
\mu \mathrm{M}) / 24 \mathrm{~h}\end{array}$ & $\begin{array}{l}\text { Co-culture with } \\
\text { HepG2/24 h }\end{array}$ & $\begin{array}{l}\text { Angiogenesis - } \\
\text { VEGF-A protein - }\end{array}$ \\
\hline $\begin{array}{l}\text { Madonna et al., } \\
2021\end{array}$ & HAECs & $\begin{array}{l}\text { EMPA }(100 \& 300 \\
\mathrm{nM}) / 0-48 \mathrm{~h} \text { DAPA } \\
(100 \mathrm{nM}) / 0-48 \mathrm{~h}\end{array}$ & $\begin{array}{l}\text { PON }(1.7 \mathrm{nM}) / 0-48 \\
\mathrm{~h}\end{array}$ & $\begin{array}{l}\text { Tube formation - } \\
\text { Cell viability - } \\
\text { Autophagy - } \\
\text { Senescence - }\end{array}$ \\
\hline $\begin{array}{l}\text { Mancini et al., } \\
2018\end{array}$ & HUVECs HAECs & $\begin{array}{l}\text { CANA }(10 \mu \mathrm{M}) / 6 \\
\& 24 \mathrm{~h}\end{array}$ & $\begin{array}{l}\mathrm{IL}-1 \beta(10 \mathrm{ng} / \mathrm{ml}) / 6 \\
\& 24 \mathrm{~h}\end{array}$ & $\begin{array}{l}\text { IL- } 6 \text { - Monocyte } \\
\text { chemoattractant } \\
\text { protein-1 - } \\
\text { Monocyte adhesion } \\
\text { - AMPK activity } \\
\text { _ }\end{array}$ \\
\hline \multirow[t]{2}{*}{$\begin{array}{l}\text { Nikolaou et al., } \\
2021\end{array}$} & Mice CMECs & $\begin{array}{l}\text { EMPA }(10 \\
\mathrm{mg} / \mathrm{kg} / \mathrm{d}) / 6 \mathrm{w}\end{array}$ & $\begin{array}{l}\text { Ischaemia }(30 \mathrm{~min}) / \\
\text { Reperfusion }(2 \mathrm{~h})\end{array}$ & $\begin{array}{l}\text { VEGF - } \\
\text { Superoxidedimutase } \\
2-\text { Cell survival }\end{array}$ \\
\hline & Human CMECs & $\begin{array}{l}\text { EMPA (500 } \\
\mathrm{nM}) / 24 \mathrm{~h}\end{array}$ & $\begin{array}{l}\text { Hypoxia }(3 \mathrm{~h}) / \\
\text { Reoxygenation (1 }\end{array}$ & $\begin{array}{l}\text { Cell viability - } \\
\text { ROS - }\end{array}$ \\
\hline
\end{tabular}

h) 


\begin{tabular}{|c|c|c|c|c|}
\hline References & Cells/Tissues & Drug (Dosage) & $\begin{array}{l}\text { Stimulant } \\
\text { (Dosage) }\end{array}$ & Major findings \\
\hline \multirow[t]{2}{*}{ Park et al., 2021} & $\begin{array}{l}\text { Porcine coronary } \\
\text { artery ECs }\end{array}$ & $\begin{array}{l}\text { EMPA or } \\
\text { sotagliflozin }(100 \\
\mathrm{nM}) / 30 \mathrm{~min}-24 \mathrm{~h}\end{array}$ & Ang II (100 nM) & $\begin{array}{l}\text { ROS - SGLT-1 \& } \\
2 \text { - Senescence } \\
\text { associated-beta- } \\
\text { galactosidase - } \\
\text { eNOS \& NO - }\end{array}$ \\
\hline & $\begin{array}{l}\text { Porcine coronary } \\
\text { artery ECs }\end{array}$ & $\begin{array}{l}\text { EMPA or } \\
\text { sotagliflozin }(100 \\
\mathrm{nM}) / 48 \mathrm{~h}\end{array}$ & $\begin{array}{l}\text { Microparticles from } \\
\text { patients with } \\
\text { coronary artery } \\
\text { disease }(10 \mathrm{nM}) / 48 \\
\text { h }\end{array}$ & $\begin{array}{l}\text { SGLT-1 \& } 2- \\
\text { eNOS \& NO - } \\
\text { VCAM-1 - }\end{array}$ \\
\hline \multirow[t]{2}{*}{ Ortega et al., 2019} & $\begin{array}{l}\text { Aortic aneurysm } \\
\text { sections of Apo E-/- } \\
\text { mice }\end{array}$ & $\begin{array}{l}\text { EMPA }(3 \\
\mathrm{mg} / \mathrm{kg} / \mathrm{d}) / 28 \mathrm{~d}\end{array}$ & $\begin{array}{l}\text { Ang II }(1000 \\
n g / k g / d) / 28 d\end{array}$ & $\begin{array}{l}\text { Macrophage } \\
\text { infiltration - p38 } \\
\text { MAPK - NF- } x B \\
\text { - VEGF - }\end{array}$ \\
\hline & HAECs & $\begin{array}{l}\text { EMPA }(3 \mu \mathrm{M}) / 24 \\
\mathrm{~h}\end{array}$ & $\begin{array}{l}\text { Ang II }(1 \mu \mathrm{M}) / 24 \\
\mathrm{~h}\end{array}$ & $\begin{array}{l}\text { Leukocyte- } \\
\text { endothelium } \\
\text { interactions - } \\
\text { ICAM-1 - } \\
\text { VCAM-1 - }\end{array}$ \\
\hline Salim et al., 2016 & $\begin{array}{l}\text { Mice abdominal } \\
\text { aorta }\end{array}$ & $\begin{array}{l}\text { Ipragliflozin }(3 \\
\mathrm{mg} / \mathrm{kg} / \mathrm{d}) / 3 \mathrm{w}\end{array}$ & STZ (150mg/lkg) & $\begin{array}{l}\text { Akt } \\
\text { phosphorylation - } \\
\text { eNOS } \\
\text { phosphorylation - } \\
\text { Monocyte } \\
\text { chemoattractant } \\
\text { protein-1 - } \\
\text { ICAM-1 - } \\
\text { VCAM-1 - }\end{array}$ \\
\hline Uthman et al., & HCAECs & EMPA (1 & TNF- $\alpha(10$ & $\mathrm{ROS}-\mathrm{NO}$ \\
\hline 2019 & HUVECs & $\begin{array}{l}\mu \mathrm{M}) / 4-24 \mathrm{~h} \\
\text { DAPA }(1 \\
\mu \mathrm{M}) / 4-24 \mathrm{~h}\end{array}$ & $\mathrm{ng} / \mathrm{ml}) / 4-24 \mathrm{~h}$ & bioavailability — \\
\hline $\begin{array}{l}\text { Uthman et al., } \\
2020\end{array}$ & HCAECs & $\begin{array}{l}\text { CANA (10 } \\
\mu \mathrm{M}) / 16 \mathrm{~h}\end{array}$ & $\begin{array}{l}\text { Lipopolysaccharide } \\
(1 \mu \mathrm{g} / \mathrm{ml}) / 16 \mathrm{~h}\end{array}$ & $\begin{array}{l}\text { IL- } 6 \text { - ERK1/2 } \\
\text { phosphorylation } \\
\text { - AMPK } \\
\text { phosphorylation } \\
\text { - HK II - }\end{array}$ \\
\hline $\begin{array}{l}\text { Uthman et al., } \\
\text { 2022 }\end{array}$ & $\begin{array}{l}\text { HCAECs } \\
\text { HUVECs }\end{array}$ & $\begin{array}{l}\text { EMPA }(1 \mu \mathrm{M}) / 6 \\
\mathrm{~h}\end{array}$ & $\begin{array}{l}\mathrm{TNF}-\alpha(10 \\
\mathrm{ng} / \mathrm{ml}) / 6 \mathrm{~h}\end{array}$ & $\begin{array}{l}\text { NHE activity - } \\
\text { Intracellular } \mathrm{Na}+ \\
\text { - ROS - }\end{array}$ \\
\hline
\end{tabular}




\begin{tabular}{|c|c|c|c|c|}
\hline References & Cells/Tissues & Drug (Dosage) & $\begin{array}{l}\text { Stimulant } \\
\text { (Dosage) }\end{array}$ & Major findings \\
\hline Zhou et al., 2018 & Mice CMECs & $\begin{array}{l}\operatorname{EMPA}(10 \\
\mathrm{mg} / \mathrm{kg} / \mathrm{d}) / 20 \mathrm{w}\end{array}$ & $\begin{array}{l}\mathrm{STZ}(50 \mathrm{mg} / \mathrm{kg}) / 5 \\
\mathrm{~d}\end{array}$ & $\begin{array}{l}\text { Angiogenesis - } \\
\text { Migration - } \\
\text { Wound healing - } \\
\text { Cytoplasmatic } \\
\text { ROS - } \\
\text { Mitochondrial } \\
\text { ROS - } \\
\text { Mitochondrial } \\
\text { fission and fusion } \\
\text { - Senescence - }\end{array}$ \\
\hline
\end{tabular}

Abbreviations: Protein kinase B (Akt); Adenosine monophosphate-activated protein kinase (AMPK); Angiotensin II (Ang II); Canagliflozin (CANA); Cardiac microvascular endothelial cell (CMEC); Dapagliflozin (DAPA); Empagliflozin (EMPA); Endothelial nitric oxide synthase (eNOS); Extracellular signal regulated kinase (ERK); Human aortic endothelial cell (HAEC); Human coronary artery endothelial cell (HCAEC); Hexokinase II (HK II); Human umbilical vein endothelial cell (HUVEC); Intracellular adhesion molecule 1 (ICAM-1); Interleukin (IL); Mitogen-activated protein kinase (MAPK); Nuclear factor kappa B (NFxB); Sodium-hydrogen exchanger (NHE); NOD-like receptor pyrin domain containing 3 (NLRP3); Nitric oxide (NO); Nicotinamide adenine dinucleotide phosphate oxidase (NOX); Ponatinib (PON); Reactive oxygen species (ROS); Sodium glucose co-transporter (SGLT); Streptozotocin (STZ); Tumor necrosis factor- $\alpha$ (TNF- $\alpha$ ); Vascular cell adhesion molecule 1 (VCAM-1); Vascular endothelial cadherin (VE-cadherin); Vascular endothelial growth factor (VEGF)

Figure legends

\section{Figure 1 :}

\section{The pivotal role of ROS in endothelial dysfunction and CM hypertrophy :}

In patients with diabetes, hyperglycaemia along with inflammatory reaction, enhanced cyclic stretch and oscillatory shear stress, increases production of reactive oxygen species in endothelial cells (ECs). ROS trigger vascular inflammation via activating multiple downstream pathways, including extracellular signal-regulating kinase (ERK), c-Jun N-terminal kinase (JNK) and p38 mitogen-activated protein kinase (p38 MAPK), as well by increasing the expression of nuclear factor kappa B (NF- $\varkappa \mathrm{B})$. Excessive ROS induce uncoupling of endothelial nitric oxide synthase (eNOS) and loss of nitric oxide (NO) bioavailability of endothelial cells. The latter results in the inactivation of protein kinase G-cyclic guanosine monophosphate (PKG-cGMP) and hypo-phosphorylation of titin in adjacent cardiomyocyte (CM), therefore promoting CM hypertrophy. Increased ROS production promotes the formation of F-actin stress fibre and vascular endothelial (VE)caherin internalisation via activing src family kinase (SFK), leading to the disruption of adherens junction (Created with Biorender.com).

\section{Figure 2}

\section{Direct endothelial protection by SGLT-2i's :}

Sodium-glucose co-transporter 2 inhibitors (SGLT-2i's) have favourable effects on endothelial cells (ECs), including (1) inhibition of reactive oxidative species (ROS) production, (2) prevention of the inflammatory reaction, (3) restoration of nitric oxide (NO) bioavailability, and (4) modulation of angiogenesis. Anti-oxidative effects of SGLT-2i's might be mediated via inhibition of nicotinamide adenine dinucleotide phosphate oxidases (NOXs), sodium-hydrogen exchanger (NHE), and mitochondrial fission. The anti-inflammatory effect of SGLT-2i's is hallmarked with downregulation of vascular cell adhesion molecule 1 (VCAM-1) and intracellular adhesion molecule 1 (ICAM-1), reduction in cytokine secretion, and prevention of monocyte-endothelium 
adhesion. SGLT-2i's might restore NO bioavailability of endothelial cells via improving phosphorylation of endothelial nitric oxide synthase (eNOS) and scavenging ROS (Created with Biorender.com).

\section{References}

Alexander SP, Fabbro D, Kelly E, Mathie A, Peters JA, Veale EL, et al. (2021). THE CONCISE GUIDE TO PHARMACOLOGY 2021/22: Catalytic receptors. Br J Pharmacol, 178 Suppl 1, S264-s312. https://doi.org/10.1111/bph.15541

Alexander SP, Kelly E, Mathie A, Peters JA, Veale EL, Armstrong JF, et al. (2021). THE CONCISE GUIDE TO PHARMACOLOGY 2021/22: Transporters. Br J Pharmacol, 178 Suppl 1, S412-s513. https://doi.org/10.1111/bph.15543

Alexander SP, Mathie A, Peters JA, Veale EL, Striessnig J, Kelly E, et al. (2021). THE CONCISE GUIDE TO PHARMACOLOGY 2021/22: Ion channels. Br J Pharmacol, 178 Suppl 1 , S157-s245. https://doi.org/10.1111/bph.15539

Alshnbari AS, Millar SA, O'Sullivan SE, \& Idris I. (2020). Effect of Sodium-Glucose Cotransporter-2 Inhibitors on Endothelial Function: A Systematic Review of Preclinical Studies. Diabetes Ther, 11 (9), 1947-1963. https://doi.org/10.1007/s13300-020-00885-z

Anker SD, Butler J, Filippatos G, Ferreira JP, Bocchi E, Bohm M, et al. (2021). Empagliflozin in Heart Failure with a Preserved Ejection Fraction. N Engl J Med . https://doi.org/10.1056/NEJMoa2107038

Apte RS, Chen DS, \& Ferrara N. (2019). VEGF in Signaling and Disease: Beyond Discovery and Development. Cell, 176 (6), 1248-1264. https://doi.org/10.1016/j.cell.2019.01.021

Baartscheer A, Schumacher CA, Wust RC, Fiolet JW, Stienen GJ, Coronel R, et al. (2017). Empagliflozin decreases myocardial cytoplasmic $\mathrm{Na}(+)$ through inhibition of the cardiac $\mathrm{Na}(+) / \mathrm{H}(+)$ exchanger in rats and rabbits. Diabetologia, 60 (3), 568-573. https://doi.org/10.1007/s00125-016-4134-x

Bai B, Yang Y, Wang Q, Li M, Tian C, Liu Y, et al. (2020). NLRP3 inflammasome in endothelial dysfunction. Cell Death Dis, 11 (9), 776. https://doi.org/10.1038/s41419-020-02985-x

Behnammanesh G, Durante ZE, Peyton KJ, Martinez-Lemus LA, Brown SM, Bender SB, et al. (2019). Canagliflozin Inhibits Human Endothelial Cell Proliferation and Tube Formation. Front Pharmacol, 10 , 362. https://doi.org/10.3389/fphar.2019.00362

Brownlee M. (2001). Biochemistry and molecular cell biology of diabetic complications. Nature, 414 (6865), 813-820. https://doi.org/10.1038/414813a

Canet F, Iannantuoni F, Marañon AM, Díaz-Pozo P, López-Domènech S, Vezza T, et al. (2021). Does Empagliflozin Modulate Leukocyte-Endothelium Interactions, Oxidative Stress, and Inflammation in Type 2 Diabetes? Antioxidants (Basel), 10 (8). https://doi.org/10.3390/antiox10081228

Cappetta D, De Angelis A, Ciuffreda LP, Coppini R, Cozzolino A, Micciche A, et al. (2020). Amelioration of diastolic dysfunction by dapagliflozin in a non-diabetic model involves coronary endothelium.Pharmacol Res, 157, 104781. https://doi.org/10.1016/j.phrs.2020.104781

Chistiakov DA, Orekhov AN, \& Bobryshev YV. (2017). Effects of shear stress on endothelial cells: go with the flow. Acta Physiol (Oxf), 219 (2), 382-408. https://doi.org/10.1111/apha.12725

Chung YJ, Park KC, Tokar S, Eykyn TR, Fuller W, Pavlovic D, et al. (2020). Off-target effects of SGLT2 blockers: empagliflozin does not inhibit $\mathrm{Na}+/ \mathrm{H}+$ exchanger-1 or lower $[\mathrm{Na}+] \mathrm{i}$ in the heart.Cardiovasc Res . https://doi.org/10.1093/cvr/cvaa323

Cooper S, Teoh H, Campeau MA, Verma S, \& Leask RL. (2019). Empagliflozin restores the integrity of the endothelial glycocalyx in vitro. Mol Cell Biochem, 459 (1-2), 121-130. https://doi.org/10.1007/s11010-019$03555-2$ 
Daiber A, Steven S, Vujacic-Mirski K, Kalinovic S, Oelze M, Di Lisa F, et al. (2020). Regulation of Vascular Function and Inflammation via Cross Talk of Reactive Oxygen and Nitrogen Species from Mitochondria or NADPH Oxidase-Implications for Diabetes Progression.Int J Mol Sci, 21 (10). https://doi.org/10.3390/ijms21103405

Damman K, Beusekamp JC, Boorsma EM, Swart HP, Smilde TDJ, Elvan A, et al. (2020). Randomized, double-blind, placebo-controlled, multicentre pilot study on the effects of empagliflozin on clinical outcomes in patients with acute decompensated heart failure (EMPA-RESPONSE-AHF). Eur J Heart Fail, 22 (4), 713-722. https://doi.org/10.1002/ejhf.1713

Devineni D, Polidori D, Curtin C, Stieltjes H, Tian H, \& Wajs E. (2016). Single-dose Pharmacokinetics and Pharmacodynamics of Canagliflozin, a Selective Inhibitor of Sodium Glucose Cotransporter 2, in Healthy Indian Participants. Clin Ther, 38 (1), 89-98 e81. https://doi.org/10.1016/j.clinthera.2015.11.008

Durante W, Behnammanesh G, \& Peyton KJ. (2021). Effects of Sodium-Glucose Co-Transporter 2 Inhibitors on Vascular Cell Function and Arterial Remodeling. Int J Mol Sci, 22 (16). https://doi.org/10.3390/ijms22168786

Eelen G, Treps L, Li X, \& Carmeliet P. (2020). Basic and Therapeutic Aspects of Angiogenesis Updated. Circ Res, 127 (2), 310-329. https://doi.org/10.1161/circresaha.120.316851

Feil R, Lehners M, Stehle D, \& Feil S. Visualising and understanding cGMP signals in the cardiovascular system. British Journal of Pharmacology, n/a (n/a). https://doi.org/https://doi.org/10.1111/bph.15500

Ferrucci L, \& Fabbri E. (2018). Inflammageing: chronic inflammation in ageing, cardiovascular disease, and frailty. Nat Rev Cardiol, 15 (9), 505-522. https://doi.org/10.1038/s41569-018-0064-2

Forrester SJ, Kikuchi DS, Hernandes MS, Xu Q, \& Griendling KK. (2018). Reactive Oxygen Species in Metabolic and Inflammatory Signaling.Circ Res, 122 (6), 877-902. https://doi.org/10.1161/CIRCRESAHA.117.311401

Forstermann U, Xia N, \& Li H. (2017). Roles of Vascular Oxidative Stress and Nitric Oxide in the Pathogenesis of Atherosclerosis.Circ Res, 120 (4), 713-735. https://doi.org/10.1161/CIRCRESAHA.116.309326

Ganbaatar B, Fukuda D, Shinohara M, Yagi S, Kusunose K, Yamada H, et al. (2020). Empagliflozin ameliorates endothelial dysfunction and suppresses atherogenesis in diabetic apolipoprotein E-deficient mice.Eur $J$ Pharmacol, 875 , 173040. https://doi.org/10.1016/j.ejphar.2020.173040

Gaspari T, Spizzo I, Liu H, Hu Y, Simpson RW, Widdop RE, et al.(2018). Dapagliflozin attenuates human vascular endothelial cell activation and induces vasorelaxation: A potential mechanism for inhibition of atherogenesis. Diab Vasc Dis Res, 15 (1), 64-73. https://doi.org/10.1177/1479164117733626

Giri B, Dey S, Das T, Sarkar M, Banerjee J, \& Dash SK. (2018). Chronic hyperglycemia mediated physiological alteration and metabolic distortion leads to organ dysfunction, infection, cancer progression and other pathophysiological consequences: An update on glucose toxicity.Biomed Pharmacother, 107 , 306-328. https://doi.org/10.1016/j.biopha.2018.07.157

Griendling KK, Camargo LL, Rios FJ, Alves-Lopes R, Montezano AC, \& Touyz RM. (2021). Oxidative Stress and Hypertension. Circulation Research, 128 (7), 993-1020. https://doi.org/doi:10.1161/CIRCRESAHA.121.318063

Haymet AB, Bartnikowski N, Wood ES, Vallely MP, McBride A, Yacoub S, et al. (2021). Studying the Endothelial Glycocalyx in vitro: What Is Missing? Front Cardiovasc Med, 8 , 647086. https://doi.org/10.3389/fcvm.2021.647086

Jin X, Liu L, Zhang Y, Xiang Y, Yin G, Lu Y, et al. (2018). Advanced Glycation End Products Enhance Murine Monocyte Proliferation in Bone Marrow and Prime Them into an Inflammatory Phenotype through MAPK Signaling. J Diabetes Res, 2018 , 2527406. https://doi.org/10.1155/2018/2527406 
Juni RP, Kuster DWD, Goebel M, Helmes M, Musters RJP, van der Velden J, et al. (2019). Cardiac Microvascular Endothelial Enhancement of Cardiomyocyte Function Is Impaired by Inflammation and Restored by Empagliflozin. JACC Basic Transl Sci, 4 (5), 575-591. https://doi.org/10.1016/j.jacbts.2019.04.003

Juni RP, Al-Shama R, Kuster DWD, van der Velden J, Hamer HM, Vervloet MG, et al. (2021). Empagliflozin restores chronic kidney disease-induced impairment of endothelial regulation of cardiomyocyte relaxation and contraction. Kidney Int, 99 (5), 1088-1101. https://doi.org/10.1016/j.kint.2020.12.013

Kaji K, Nishimura N, Seki K, Sato S, Saikawa S, Nakanishi K, et al. (2018). Sodium glucose cotransporter 2 inhibitor canagliflozin attenuates liver cancer cell growth and angiogenic activity by inhibiting glucose uptake. Int J Cancer, 142 (8), 1712-1722. https://doi.org/10.1002/ijc.31193

Kay AM, Simpson CL, \& Stewart JA, Jr. (2016). The Role of AGE/RAGE Signaling in Diabetes-Mediated Vascular Calcification. J Diabetes Res, 2016 , 6809703. https://doi.org/10.1155/2016/6809703

Khemais-Benkhiat S, Belcastro E, Idris-Khodja N, Park SH, Amoura L, Abbas M, et al. (2020). Angiotensin II-induced redox-sensitive SGLT1 and 2 expression promotes high glucose-induced endothelial cell senescence. J Cell Mol Med, 24 (3), 2109-2122. https://doi.org/10.1111/jcmm.14233

Kleinbongard P, Bøtker HE, Ovize M, Hausenloy DJ, \& Heusch G. (2020). Co-morbidities and co-medications as confounders of cardioprotection-Does it matter in the clinical setting? British Journal of Pharmacology, 177 (23), 5252-5269. https://doi.org/https://doi.org/10.1111/bph.14839

Klug NR, Chechneva OV, Hung BY, \& O'Donnell ME. (2021). High glucose-induced effects on $\mathrm{Na}(+)$ $\mathrm{K}(+)-2 \mathrm{Cl}(-)$ cotransport and $\mathrm{Na}(+) / \mathrm{H}(+)$ exchange of blood-brain barrier endothelial cells: involvement of SGK1, PKCbetaII, and SPAK/OSR1. Am J Physiol Cell Physiol, 320 (4), C619-C634. https://doi.org/10.1152/ajpcell.00177.2019

Kolijn D, Pabel S, Tian Y, Lódi M, Herwig M, Carrizzo A, et al.(2020). Empagliflozin improves endothelial and cardiomyocyte function in human heart failure with preserved ejection fraction via reduced pro-inflammatory-oxidative pathways and protein kinase $\mathrm{G} \alpha$ oxidation.Cardiovascular Research, 117 (2), 495-507. https://doi.org/10.1093/cvr/cvaa123

Król M, \& Kepinska M. (2021). Human Nitric Oxide Synthase - Its Functions, Polymorphisms, and Inhibitors in the Context of Inflammation, Diabetes and Cardiovascular Diseases. International Journal of Molecular Sciences, 22 (1), 56.

Kruger-Genge A, Blocki A, Franke RP, \& Jung F. (2019). Vascular Endothelial Cell Biology: An Update. Int J Mol Sci, 20 (18). https://doi.org/10.3390/ijms20184411

Kuno A, Kimura Y, Mizuno M, Oshima H, Sato T, Moniwa N, et al.(2020). Empagliflozin attenuates acute kidney injury after myocardial infarction in diabetic rats. Sci Rep, 10 (1), 7238. https://doi.org/10.1038/s41598-020-64380-y

Lehoux S. (2006). Redox signalling in vascular responses to shear and stretch. Cardiovascular Research, 71 2, 269-279.

Leng W, Ouyang X, Lei X, Wu M, Chen L, Wu Q, et al. (2016). The SGLT-2 Inhibitor Dapagliflozin Has a Therapeutic Effect on Atherosclerosis in Diabetic ApoE(-/-) Mice. Mediators Inflamm, 2016 , 6305735. https://doi.org/10.1155/2016/6305735

Li X, Römer G, Kerindongo RP, Hermanides J, Albrecht M, Hollmann MW, et al. (2021). Sodium Glucose Co-Transporter 2 Inhibitors Ameliorate Endothelium Barrier Dysfunction Induced by Cyclic Stretch through Inhibition of Reactive Oxygen Species. International Journal of Molecular Sciences, 22 (11), 6044. https://www.mdpi.com/1422-0067/22/11/6044

Lin M, Chen Y, Jin J, Hu Y, Zhou KK, Zhu M, et al. (2011). Ischaemia-induced retinal neovascularisation and diabetic retinopathy in mice with conditional knockout of hypoxia-inducible factor-1 in retinal Muller 
cells. Diabetologia, 54 (6), 1554-1566. https://doi.org/10.1007/s00125-011-2081-0

Litvinukova M, Talavera-Lopez C, Maatz H, Reichart D, Worth CL, Lindberg EL, et al. (2020). Cells of the adult human heart. Nature, 588 (7838), 466-472. https://doi.org/10.1038/s41586-020-2797-4

Luo J, Sun P, Zhang X, Lin G, Xin Q, Niu Y, et al. (2021). Canagliflozin Modulates Hypoxia-Induced Metastasis, Angiogenesis and Glycolysis by Decreasing HIF-1 $\alpha$ Protein Synthesis via AKT/mTOR Pathway.Int J Mol Sci, 22 (24). https://doi.org/10.3390/ijms222413336

Madonna R, Barachini S, Moscato S, Ippolito C, Mattii L, Lenzi C, et al. (2021). Sodium-glucose cotransporter type 2 inhibitors prevent ponatinib-induced endothelial senescence and disfunction: A potential rescue strategy. Vascul Pharmacol, 142 , 106949. https://doi.org/10.1016/j.vph.2021.106949

Mancini SJ, Boyd D, Katwan OJ, Strembitska A, Almabrouk TA, Kennedy S, et al. (2018). Canagliflozin inhibits interleukin-1beta-stimulated cytokine and chemokine secretion in vascular endothelial cells by AMP-activated protein kinase-dependent and -independent mechanisms. Sci Rep, 8 (1), 5276. https://doi.org/10.1038/s41598-018-23420-4

Meza CA, La Favor JD, Kim DH, \& Hickner RC. (2019). Endothelial Dysfunction: Is There a HyperglycemiaInduced Imbalance of NOX and NOS? Int J Mol Sci, 20 (15). https://doi.org/10.3390/ijms20153775

Monteiro JP, Bennett M, Rodor J, Caudrillier A, Ulitsky I, \& Baker AH. (2019). Endothelial function and dysfunction in the cardiovascular system: the long non-coding road. Cardiovascular Research, 115 (12), 1692-1704. https://doi.org/10.1093/cvr/cvz154

Neal B, Perkovic V, Mahaffey KW, de Zeeuw D, Fulcher G, Erondu N, et al. (2017). Canagliflozin and Cardiovascular and Renal Events in Type 2 Diabetes. $N$ Engl J Med, 377 (7), 644-657. https://doi.org/10.1056/NEJMoa1611925

Nikolaou PE, Efentakis P, Abu Qourah F, Femminò S, Makridakis M, Kanaki Z, et al. (2021). Chronic Empagliflozin Treatment Reduces Myocardial Infarct Size in Nondiabetic Mice Through STAT-3-Mediated Protection on Microvascular Endothelial Cells and Reduction of Oxidative Stress. Antioxidants Redox Signaling, 34 (7), 551-571. https://doi.org/10.1089/ars.2019.7923

Ohgaki R, Wei L, Yamada K, Hara T, Kuriyama C, Okuda S, et al.(2016). Interaction of the Sodium/Glucose Cotransporter (SGLT) 2 inhibitor Canagliflozin with SGLT1 and SGLT2. J Pharmacol Exp Ther, 358 (1), 94-102. https://doi.org/10.1124/jpet.116.232025

Ohishi M. (2018). Hypertension with diabetes mellitus: physiology and pathology. Hypertens Res, 41 (6), 389-393. https://doi.org/10.1038/s41440-018-0034-4

Okonkwo UA, \& DiPietro LA. (2017). Diabetes and Wound Angiogenesis.Int J Mol Sci, 18 (7). https://doi.org/10.3390/ijms18071419

Ortega R, Collado A, Selles F, Gonzalez-Navarro H, Sanz M-J, Real JT, et al. (2019). SGLT-2 (SodiumGlucose Cotransporter 2) Inhibition Reduces Ang II (Angiotensin II)-Induced Dissecting Abdominal Aortic Aneurysm in ApoE (Apolipoprotein E) Knockout Mice.Arteriosclerosis, Thrombosis, and Vascular Biology, 39 (8), 1614-1628. https://doi.org/doi:10.1161/ATVBAHA.119.312659

Packer M. (2020). Molecular, Cellular, and Clinical Evidence That Sodium-Glucose Cotransporter 2 Inhibitors Act as Neurohormonal Antagonists When Used for the Treatment of Chronic Heart Failure.J Am Heart Assoc, 9 (16), e016270. https://doi.org/10.1161/jaha.120.016270

Packer M, Anker SD, Butler J, Filippatos G, Pocock SJ, Carson P, et al. (2020). Cardiovascular and Renal Outcomes with Empagliflozin in Heart Failure. $N$ Engl $J$ Med, 383 (15), 1413-1424. https://doi.org/10.1056/NEJMoa2022190

Park SH, Belcastro E, Hasan H, Matsushita K, Marchandot B, Abbas M, et al. (2021). Angiotensin II-induced upregulation of SGLT1 and 2 contributes to human microparticle-stimulated endothelial senescence and 
dysfunction: protective effect of gliflozins. Cardiovasc Diabetol, 20 (1), 65. https://doi.org/10.1186/s12933021-01252-3

Rastogi R, Geng X, Li F, \& Ding Y. (2016). NOX Activation by Subunit Interaction and Underlying Mechanisms in Disease. Front Cell Neurosci, 10 , 301. https://doi.org/10.3389/fncel.2016.00301

Ritchie RH, \& Abel ED. (2020). Basic Mechanisms of Diabetic Heart Disease. Circulation Research, 126 (11), 1501-1525. https://doi.org/doi:10.1161/CIRCRESAHA.120.315913

Saeidnia S, Manayi A, \& Abdollahi M. (2015). From in vitro Experiments to in vivo and Clinical Studies; Pros and Cons. Curr Drug Discov Technol, 12 (4), 218-224. https://doi.org/10.2174/1570163813666160114093140

Salim HM, Fukuda D, Yagi S, Soeki T, Shimabukuro M, \& Sata M. (2016). Glycemic Control with Ipragliflozin, a Novel Selective SGLT2 Inhibitor, Ameliorated Endothelial Dysfunction in Streptozotocin-Induced Diabetic Mouse. Front Cardiovasc Med, 3, 43. https://doi.org/10.3389/fcvm.2016.00043

Salvatore T, Caturano A, Galiero R, Di Martino A, Albanese G, Vetrano E, et al. (2021). Cardiovascular Benefits from Gliflozins: Effects on Endothelial Function. Biomedicines, 9 (10). https://doi.org/10.3390/biomedicines9101356

Sayour AA, Korkmaz-Icoz S, Loganathan S, Ruppert M, Sayour VN, Olah A, et al. (2019). Acute canagliflozin treatment protects against in vivo myocardial ischemia-reperfusion injury in non-diabetic male rats and enhances endothelium-dependent vasorelaxation. J Transl Med, 17 (1), 127. https://doi.org/10.1186/s12967019-1881-8

Seferovic PM, Petrie MC, Filippatos GS, Anker SD, Rosano G, Bauersachs J, et al. (2018). Type 2 diabetes mellitus and heart failure: a position statement from the Heart Failure Association of the European Society of Cardiology. Eur J Heart Fail, 20 (5), 853-872. https://doi.org/10.1002/ejhf.1170

Shah AK, Bhullar SK, Elimban V, \& Dhalla NS. (2021). Oxidative Stress as A Mechanism for Functional Alterations in Cardiac Hypertrophy and Heart Failure. Antioxidants (Basel), 10 (6). https://doi.org/10.3390/antiox10060931

Shah SJ, Lam CSP, Svedlund S, Saraste A, Hage C, Tan RS, et al.(2018). Prevalence and correlates of coronary microvascular dysfunction in heart failure with preserved ejection fraction: PROMIS-HFpEF.Eur Heart J, 39 (37), 3439-3450. https://doi.org/10.1093/eurheartj/ehy531

Shi Y, \& Vanhoutte PM. (2017). Macro- and microvascular endothelial dysfunction in diabetes. J Diabetes, 9 (5), 434-449. https://doi.org/10.1111/1753-0407.12521

Siu KL, Gao L, \& Cai H. (2016). Differential Roles of Protein Complexes NOX1-NOXO1 and NOX2-p47phox in Mediating Endothelial Redox Responses to Oscillatory and Unidirectional Laminar Shear Stress. J Biol Chem, 291 (16), 8653-8662. https://doi.org/10.1074/jbc.M115.713149

Toldo S, Mezzaroma E, Buckley LF, Potere N, Di Nisio M, Biondi-Zoccai G, et al. (2021). Targeting the NLRP3 inflammasome in cardiovascular diseases. Pharmacol Ther, 236 , 108053. https://doi.org/10.1016/j.pharmthera.2021.108053

Tomlinson B, Hu M, Zhang Y, Chan P, \& Liu ZM. (2017). Evaluation of the pharmacokinetics, pharmacodynamics and clinical efficacy of empagliflozin for the treatment of type 2 diabetes. Expert Opin Drug Metab Toxicol, 13 (2), 211-223. https://doi.org/10.1080/17425255.2017.1258401

Trum M, Riechel J, \& Wagner S. (2021). Cardioprotection by SGLT2 Inhibitors-Does It All Come Down to $\mathrm{Na}(+)$ ? Int J Mol Sci, 22 (15). https://doi.org/10.3390/ijms22157976

Umapathy A, Chamley LW, \& James JL. (2020). Reconciling the distinct roles of angiogenic/anti-angiogenic factors in the placenta and maternal circulation of normal and pathological pregnancies. Angiogenesis, 23 (2), 105-117. https://doi.org/10.1007/s10456-019-09694-w 
Uthman L, Baartscheer A, Bleijlevens B, Schumacher CA, Fiolet JWT, Koeman A, et al. (2018). Class effects of SGLT2 inhibitors in mouse cardiomyocytes and hearts: inhibition of $\mathrm{Na}(+) / \mathrm{H}(+)$ exchanger, lowering of cytosolic $\mathrm{Na}(+)$ and vasodilation. Diabetologia, 61 (3), 722-726. https://doi.org/10.1007/s00125-017-4509-7

Uthman L, Baartscheer A, Schumacher CA, Fiolet JWT, Kuschma MC, Hollmann MW, et al. (2018). Direct Cardiac Actions of Sodium Glucose Cotransporter 2 Inhibitors Target Pathogenic Mechanisms Underlying Heart Failure in Diabetic Patients. Front Physiol, 9 , 1575. https://doi.org/10.3389/fphys.2018.01575

Uthman L, Homayr A, Juni RP, Spin EL, Kerindongo R, Boomsma M, et al. (2019). Empagliflozin and Dapagliflozin Reduce ROS Generation and Restore NO Bioavailability in Tumor Necrosis Factor alpha-Stimulated Human Coronary Arterial Endothelial Cells. Cell Physiol Biochem, 53 (5), 865-886. https://doi.org/10.33594/000000178

Uthman L, Kuschma M, Romer G, Boomsma M, Kessler J, Hermanides J, et al. (2020). Novel Antiinflammatory Effects of Canagliflozin Involving Hexokinase II in Lipopolysaccharide-Stimulated Human Coronary Artery Endothelial Cells. Cardiovasc Drugs Ther . https://doi.org/10.1007/s10557-020-07083-w

Uthman L, Li X, Baartscheer A, Schumacher CA, Baumgart P, Hermanides J, et al. (2022). Empagliflozin reduces oxidative stress through inhibition of the novel inflammation/NHE/[Na+]c/ROSpathway in human endothelial cells. Biomedicine \& Pharmacotherapy, 146 , 112515. https://doi.org/https://doi.org/10.1016/j.biopha.2021.112515

Wiviott SD, Raz I, Bonaca MP, Mosenzon O, Kato ET, Cahn A, et al.(2019). Dapagliflozin and Cardiovascular Outcomes in Type 2 Diabetes. $N$ Engl J Med, 380 (4), 347-357. https://doi.org/10.1056/NEJMoa1812389

Yuan T, Yang T, Chen H, Fu D, Hu Y, Wang J, et al. (2019). New insights into oxidative stress and inflammation during diabetes mellitus-accelerated atherosclerosis. Redox Biol, 20 , 247-260. https://doi.org/10.1016/j.redox.2018.09.025

Zhang WJ, Li PX, Guo XH, \& Huang QB. (2017). Role of moesin, Src, and ROS in advanced glycation end product-induced vascular endothelial dysfunction. Microcirculation, 24 (3). https://doi.org/10.1111/micc.12358

Zhou H, Wang S, Zhu P, Hu S, Chen Y, \& Ren J. (2018). Empagliflozin rescues diabetic myocardial microvascular injury via AMPK-mediated inhibition of mitochondrial fission. Redox Biol, 15 , 335-346. https://doi.org/10.1016/j.redox.2017.12.019

Zinman B, Wanner C, Lachin JM, Fitchett D, Bluhmki E, Hantel S, et al. (2015). Empagliflozin, Cardiovascular Outcomes, and Mortality in Type 2 Diabetes. $N$ Engl J Med, 373 (22), 2117-2128. https://doi.org/10.1056/NEJMoa1504720

Zuurbier CJ, Demirci C, Koeman A, Vink H, \& Ince C. (2005). Short-term hyperglycemia increases endothelial glycocalyx permeability and acutely decreases lineal density of capillaries with flowing red blood cells. $J$ Appl Physiol (1985), 99 (4), 1471-1476. https://doi.org/10.1152/japplphysiol.00436.2005

Zuurbier CJ, Baartscheer A, Schumacher CA, Fiolet JWT, \& Coronel R. (2021). SGLT2 inhibitor empagliflozin inhibits the cardiac $\mathrm{Na}+/ \mathrm{H}+$ exchanger 1: persistent inhibition under various experimental conditions. Cardiovasc Res . https://doi.org/10.1093/cvr/cvab129 

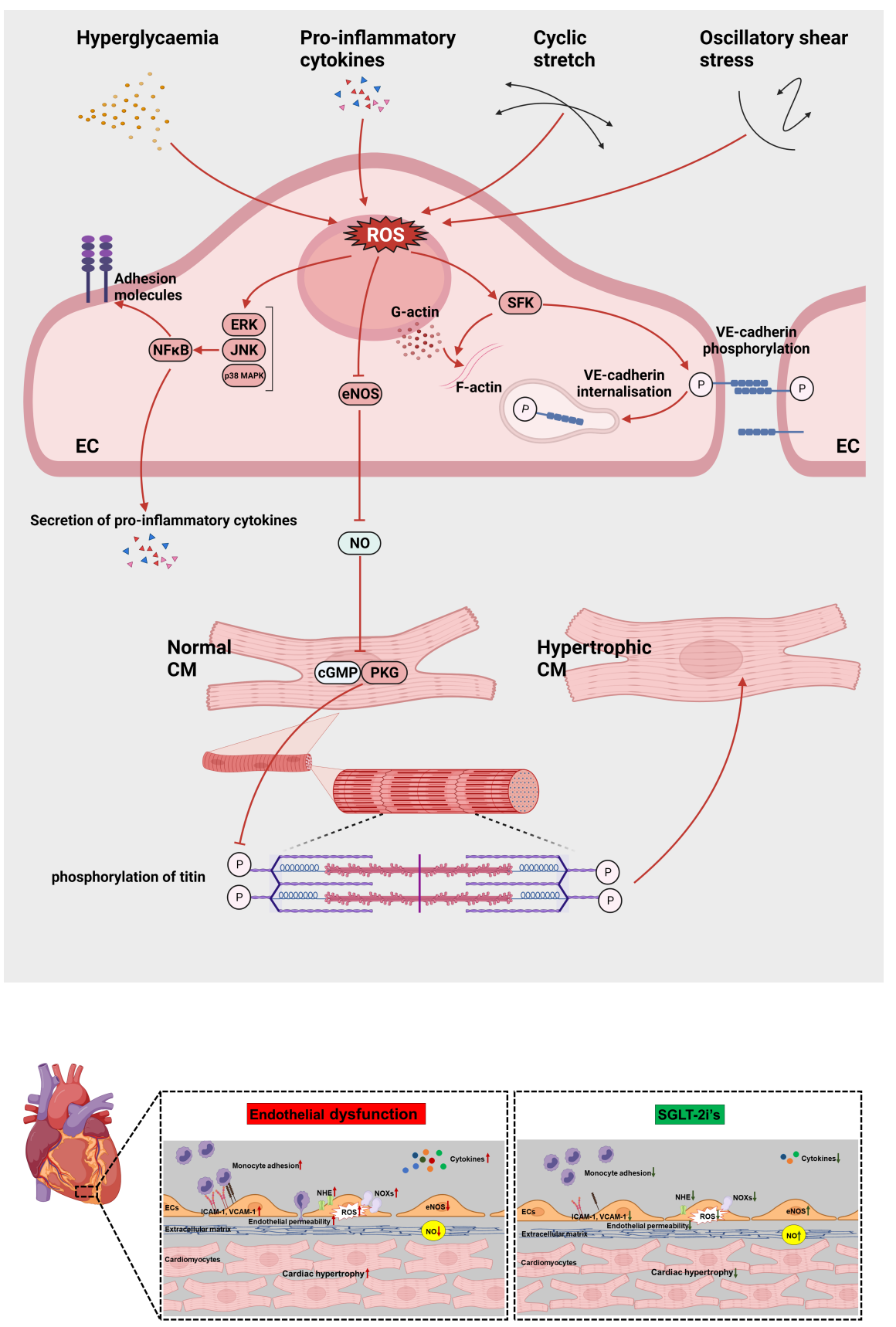